\title{
Examination of the Basement of Historic Buildings in Investment Activity
}

\author{
Aleksey Ulybin ${ }^{1, *}$, Aleksandr Lanko ${ }^{1}$, Nikolai Vatin $^{1}$, and Katerina Lysnytska ${ }^{2}$ \\ ${ }^{1}$ Peter the Great St. Petersburg Polytechnic University, Polytechnicheskaya 29, 195251 St. Petersburg, \\ Russia \\ ${ }^{2}$ National Aviation University, 03058, Kosmonavta Komarova, 1, Kyiv, Ukraine
}

\begin{abstract}
The process and methodology of the survey of basements rarely mentioned in the various construction rules and regulations. Basically describes the procedure of conducting a detailed survey of some of the individual elements. These surveys are fundamental in nature, include a large number of estimates and require significant financial and time costs. Usually the purpose of these surveys is to check the state of the building as a whole, it's safe operation or before starting of reconstruction. In the process of selecting areas of investment activity such large-scale survey is not possible. Needed a quick and inexpensive method intended for decision about investment in a particular object. At the same time, the survey should cover all the elements of the basement significantly affect the cost of reconstruction of the basement associated with his penetration. The article presents the general conception of conducting a rapid survey. The described methods and technologies applicable to the examination for the purpose of making decisions about investments in reconstruction of a basement level rooms. The composition of the works and their sequence. A comparison of the advantages and disadvantages of different methods. The practical examples. Scheme of conducting a rapid survey of the basement. The article analyzes the materials used in the construction of historic buildings in St. Petersburg.
\end{abstract}

\section{Introduction}

In today's world investors, specializing in real estate, need to look for new opportunities to find the "extra" square meters. For cities with a long history, particularly cities where the cost of commercial real estate in central, generally historical part of the city is significantly higher than on the outskirts, reconstruction of existing buildings, is relevant. One notable example is St Petersburg, where every year a large number of houses were also renovated in the form of deepening of the basement level rooms. The foundations of such houses are mostly rubble, made from local stone materials, often with the presence of wooden elements - beams, raft foundations, piles. As stone materials were used in the early years of the building of Saint Petersburg rounded rocks (boulders of igneous or metamorphic rocks), in later periods no rounded rock fragments (platy stone from limestone, dolomite,

\footnotetext{
* Corresponding author: $\underline{\text { ulybin } @ \text { mail.ru }}$
} 
sandstone). Sometimes doing the whole foundation with brick of burnt brick. The most widespread rubble foundation as a building material was used mainly platy limestone. The foundations were carried out, as a rule, in the trenches, which were dug out without fixing, with vertical walls. The wooden elements in the foundations of historic buildings in the form of sills from logs with a diameter of $27-33 \mathrm{~cm}$, stacked on a bottom of the trench or piles no longer than 6-9 m scored in the soil at the bottom of the trenches, were used in the presence of weak soils and high ground water. Historically, existing basements, as a rule, are not adapted for facilities management in modern conditions, do not meet modern standards and need to increase their height. To investors the problem of determining the volume and composition of works to bring the premises into compliance with the goals and objectives of future use. We need to develop a simple and versatile algorithm to survey the basement for the purpose of decision making about reconstruction. Certainly the results of the survey can only be used for choosing the object of investment, but not to begin work on the development of the project. For the development of the project of reconstruction it is necessary to perform complex research and survey work to identify the actual technical condition of the building and the activities of its recovery $[1,2]$.

Currently you can find a huge number of works devoted to the problem of inspection of buildings [3-15], but mostly they are devoted to a detailed examination. The main objective of this work is to develop the most simple, fast and inexpensive method of examination of different elements of the building for the purpose of making the decision to reconstruct the basement. The novelty in this approach lies in the fact that the survey is not conducted for the purpose of the reconstruction, and for the purpose of making any investment decision, the investor who takes the decision to invest in this space. In contrast to the detailed survey, which devoted the most part of scientific works, the investor has no time and funds to carry out these examination. Reducing the cost of operations in this case are "at the forefront" in the competition for a particular object [16]. Often when buying premises there is no possibility of conducting any survey except visual. A striking example of such scheme of sale of bidding areas are held by the Property Fund of St. Petersburg [17]. During the inspection of the premises at these auctions only allowed a visual inspection of the premises. In this paper we consider the case when the investor can still do the testing, does not violate the integrity and value of the proposed premises. Of course the time factor and the cost of works will continue to solve critical role.

\section{Description of the study}

The objective of the study is to develop a survey as soon as possible, create a comprehensive survey method based on the combination of various existing methods. The examination should include all necessary elements endemic areas and the building as a whole:

- exterior walls and walls in basement level rooms;

- the foundation of the building;

- the ceiling of the basement level rooms;

- utilities passing through the basement.

Definitely perfect for these parameters, visual method, but in most cases it does not give results sufficient for decision making about investments in a basement. Unfortunately, most of the grounds of the building are not accessible for visual examination method, namely the condition of the grounds of the building is the defining element in assessing the amount of future

investments.

The first thing to do would be to visually inspect the walls of the building under which is located the basement. Unfortunately, it is difficult to find a universal algorithm for visual inspection, in the modern normative documents, there is practically no guidance on the 
procedure for conducting surveys, about the sequence of actions [18]. For the purposes of this survey, it is necessary to inspect both the front and the courtyard section. Should identify the presence and parameters of cracks: the breadth and depth of disclosure, the location, length, angle of inclination, nature of origin. The detection characteristic of cracks, distortions of parts of the building, fissures of walls and other damage and deformation indicates poor base condition. In this case, conducting a detailed survey to identify causes of deformations is required and further conduct a rapid survey is not advisable. To determine the "critical point" after which there is a high degree of probability to argue that the deepening of the basement will require strengthening of bases you can use the tables proposed in VSN 53-86(R) [19] to determine the physical wear of belt stone foundations and brick walls. According to this document depreciation of $40 \%$ requires a significant strengthening of structures. This level of damage speaks about the critical condition of basements and foundations of buildings and, with high probability, will require strengthening. Thus, in the first stage of the rapid survey after the visual detection method physical deterioration of the walls and visible portions of the foundations more than $40 \%$ discontinue further examination. According to VSN 53-86(R) this wear has the following features: "the buckling and noticeable curvature of the basement, through cracks in the basement with the development of the full height of the building, buckling floors and walls of basement" [19]. Also a quantitative assessment of the degree of wear: "Uneven, precipitate with common deflection walls to 0.02 of its length" [19]. Unfortunately, these parameters determine the physical wear is outdated and requires amendment. For example, decrease the pitch degree of physical deterioration is at least 2, preferably 4 times. At the present time step is $20 \%$. However in this survey they are perfectly applicable.

After visual inspection of the walls and visible portions of the Foundation necessary to proceed to survey the hidden part of the basement. For investor purposes the examination of the grounds of the building, when evaluating investments in a basement are:

- determining the status of the hidden part of the basement;

- definition of the depth of the foundation base;

- determination of groundwater levels and their intensity;

- the presence of a wooden ledge.

The main difficulty of this stage is the need for excavation or drilling operations, which is not always possible when considering the acquisition of a basement. The consent of the current owner to carry out these works. In case of impossibility of the above works, the study will be limited to preliminary visual inspection, which in most cases does not allow to make a reliable prediction about the possible costs of reconstruction of the premises. In this, unfavorable to the investor case, you should stop the rapid survey and to conduct a detailed examination, or to refuse investments. With the consent of the current owner for excavation or drilling operations, you should choose one of the three types of work:

- drilling holes by perforator;

- drilling of cores by diamond drilling machine;

- digging of pit.

Each of these methods has its advantages and disadvantages and choose the type of work should be based on the specific situation.

In the course of examination of a basement in the street Blohina of the Petrograd district of St. Petersburg was a comparison of the advantages and disadvantages of the above methods. 3 dug pit at the base of the Foundation and conducted one trial drilling rig. Methods of examination of grounds of building a drilling rig is described in detail in the work of Kolmogorova S. S. [27]. On the digging of one pit left in an average of about 8 man hours, with most of the work had to be performed below the groundwater level, constantly evacuating the water which was an additional difficulty. Also had to use a heavy jackhammer to overcome the floor plate 30 centimeters wide, the drilling of a single core 
took about 4 hours, the nature of the work were substantially lighter in nature, less physical labor. Data on the depth of the Foundation and the groundwater level coincided. The difference was less than 5 centimeters.

Examination by excavation of a pit requires large time and cost, but has a number of advantages. Inspection pit allows you to define the cross section of the Foundation from sinking, which is impossible when core drilling. Additionally, the pit is more evident, when it is adopt is exposed about one meter of the Foundation base that allows you to make more accurate measurements. The main disadvantage of the excavation pit is the extent of damage to the cellar. Destroyed not less than 1 square meter of the floor, this disturbed the waterproofing of floor, more expensive to restore.

Drilling of cores is important when large areas of the basement (over $200 \mathrm{~m} 2$ ) or the complex configuration of the basement, when according to GOST 31937-2011 [20] requires a large number (more than 10) cores. In small areas where you can be limited to 23 points, especially in the case of ground floors, on the contrary, the digging of pits is preferable.

Drilling holes by perforator is the most quick and inexpensive way to survey the hidden part of the Foundation, but it is the least informative. With the help of drilling of the hole to determine the depth of the Foundation, but the data collected in this way are less accurate than revealed by the excavation of pits or drill core. Accurate determination of current groundwater levels and their degree of intensity is not possible.

The choice of survey method the hidden part of the basement and foundations is influenced by:

- negotiation with the current owner of the particular method;

- the data type that you want to receive with the survey;

- the size and complexity of the configuration of the basement level rooms;

- material of the floors of the basement level rooms.

During practical examination of a basement on Blokhina street in St. Petersburg was drawn up a comparison table (Table 1) of examination methods of the hidden parts of the basement.

Table 1. Comparison methods of excavation the pit and drill core.

\begin{tabular}{|c|c|c|}
\hline & $\begin{array}{c}\text { Method of drilling } \\
\text { borehole }\end{array}$ & $\begin{array}{c}\text { The method of digging the } \\
\text { pit }\end{array}$ \\
\hline $\begin{array}{c}\text { Speed survey for } \\
\text { one object }\end{array}$ & 4 man/hour & L man/hour \\
\hline Damage from the survey & Small & Large \\
\hline $\begin{array}{c}\text { Measure the depth of } \\
\text { Foundation base }\end{array}$ & Yes & Yes \\
\hline $\begin{array}{c}\text { Drawing the cross section } \\
\text { of the Foundation }\end{array}$ & No & Yes \\
\hline $\begin{array}{c}\text { Measurements of } \\
\text { groundwater level }\end{array}$ & Yes & Yes \\
\hline $\begin{array}{c}\text { Measurement of the } \\
\text { nature of groundwater }\end{array}$ & No & Yes \\
\hline $\begin{array}{c}\text { Determination of the } \\
\text { presence of wooden sills }\end{array}$ & Yes & \\
\hline
\end{tabular}

Regardless of the choice of survey method the hidden part of the basement in the first place should determine the depth of the Foundation base. According to calculations by various authors [21,22] when the distance from the sole of the basement floor to the basement at 50 centimeters or more in most cases there is no risk of the lifting soils and 
additional amplification is not required. This is confirmed by various building codes and regulations for the design of foundations. For example in 50-302-2004 TSN: "the Depth of the base of the foundations from the floor of the underground (basement) shall not be less than $50 \mathrm{~cm}$ " [23]. Indirectly this is confirmed by SP 50-101-2004: "allowed to take the depth of the Foundation from the basement floor less than $0.5 \mathrm{~m}$, if the calculation on bearing capacity" [24]. Thus one of the fundamental factors in the rapid method is the distance from the ceiling of the basement (ceiling between the first floor and basement) to the soles of the Foundation. This distance will allow us to determine what the maximum ceiling height of the basement level room is possible to achieve without strengthening the foundations of the building (Eq 1). As a rule the process of strengthening of the bases is so time-consuming and expensive that the reconstruction of the basement coupled with this process is not appropriate.

$$
H_{\max }=S-h_{\text {safe }}-h_{\text {floor }}
$$

Where:

$\mathrm{H}_{\max }$ - the maximum height of a basement level room can be achieved without strengthening the foundations of the building;

$\mathrm{S}$ - the distance from the Foundation base to the ceiling between basement and first floors;

$\mathrm{h}_{\text {safe }}$ - minimal layer of sole Foundation, preventing lifting the soil from under the basement, is taken to be equal 50 centimeters.

$\mathrm{h}_{\text {floor }}$ - height of floor "pie".

If the estimated height of the ceiling suits the customer based on the intended use and requirements, we should continue the rapid survey. In the case where the estimated height is not enough for operation of the premises, it requires detailed examination for planning of measures on strengthening of the bases. In such unfavorable for the investor case, you should refuse further Express survey.

After determining the calculated height of the basement with the requirements of the customer, it is necessary to determine the groundwater level. This indicator will significantly affect the cost of waterproofing the room. According to the report of Nikolaev and A. S. Savenkova, G. B. ground in St. Petersburg is represented everywhere at depths of from 0.5 to 3.5 meters [25]. The report presents a detailed map of groundwater level in St. Petersburg. Thus, in an ideal for the investor case, there is a possibility that the planned floor of the basement is above the ground water level. The described situation is possible with "high" basements, when a significant portion of the basement level room located above ground level. In such cases, it is possible to confine a light waterproofing that protects against short-term pressures of groundwater. However, you have to take into account seasonal fluctuation of groundwater that can be significant To determine fluctuations in ground waters, in 2008, according to the results of groundwater monitoring of the territorial reach of the state unitary company "SF "Mineral", was built the digital map of maximum predicted groundwater levels in St. Petersburg (the authors Savenkova, G. B., Fedyk, G. N.) [26]. However, the determination of the current level of groundwater directly to the site of the planned reconstruction is important when calculating the cost of works on waterproofing of the room. According to the report of Nikolaev and A. S. Savenkova, G. B. ground water of St. Petersburg are unconfined in nature, which makes possible the waterproofing of basements, but the identification of confined groundwater of the upper pressure aquifer can significantly increase the cost of waterproofing the space and make it a reconstruction is not feasible. Definition of groundwater level can be performed both by the open pit and drilled to the core. However, monitoring of the groundwater level in the pit is preferable to determine the velocity of the water after pumping to detect possible discharge 
of groundwater. After finding the level of groundwater should determine the presence of a wooden ledge under the base and their status. According to research by Kolmogorsky S. S. wooden sills occur in about $20 \%$ of foundations of historical buildings in St. Petersburg [27]. As mentioned previously, the presence of a wooden ledge is a dangerous character by lowering the level of ground water below the ledge. In this undesirable case, the wooden ledge beginning to crumble. S. I. Alekseev in his work [28] says that the process of decay in this case can go so intense that destroys the wood for 3-5 years and inevitably leads to uneven precipitation of additional seals. Thus, the presence of a wooden sills and their location must be considered in the groundwater during the reconstruction of a basement, and if you install the emergency sump pump. Undoubtedly, when it detects the wooden sills should abandon the method of penetration of a basement associated with a long-term lowering of the groundwater level in case if it is below the level of the ledge.

The survey of slabs should be limited to a visual examination. A detailed survey and calculations are expensive and in need of reconciliation. Preliminary examination set the type of overlap (in the form of materials and design features), visible defects and damage, the condition of individual parts of the floors, repaired or enhanced, the existing floor load. When inspecting the slabs record the presence, length and opening width of cracks in the supporting elements or their mates. The deflections of the slabs is determined using methods of geometric and hydrostatic leveling. When carrying out a survey of overlaps detected by the visual method:

For reinforced concrete floors, available:

- deflection in excess of the permitted, possibly with the formation of cracks in the bottom (tensile) zone of reinforced concrete elements caused by exceeding the design load;

- peeling, cracking, blistering or flaking of coatings;

- loss of mortar from joints between precast concrete slabs;

- moisture, efflorescence, rust stains.

To masonry(brick) arches:

- cracks and other damage in the masonry vaults of stone (breaking up of stones of the arches in the castle, the quarters of the span or at the supports, loss of individual stones);

-stratification and a breakdown of the masonry of the vaults caused a significant overload of masonry.

For slabs on girders:

- determine the deflections, possibly with the formation of cracks in small vaults;

- access to beams is determined by the estimated size of the beam, the corrosion of the visible part of the beam (usually the bottom shelf).

The final stage is the examination of utilities that are located indoors. Their status and position can significantly affect to the cost of works on reconstruction of a basement. The examination of heating systems, hot and cold water to produce a survey of the corrosion condition of pipelines and heating devices. The corrosion state is measured by the maximum depth of corrosion of the metal wall and the average value of the narrowing section of pipe corrosion scale deposits in comparison with a new tube. The allowable value of maximum relative depth of corrosion damage of pipes should be taken equal to $50 \%$ of the wall thickness of the new pipe. Examination of corrosion condition of pipes allows to estimate the amount of communication needed to be replaced.

The next important element is the examination of engineering communications is to assess the possibility and necessity of migration networks within the basement. This situation often occurs when their location makes it impossible to use this basement for alleged purposes. As a rule of communication pass through the center of the room, occupying a large space, significantly reducing the "useful volume" of the room.In addition, when planning the formation of new openings, exits from the premises, you may also need to transfer communications. At this stage you should assess the amount and type of utilities 
to be transferred.The General concept of conducting a rapid survey is reflected in the algorithm of Fig. 1 .

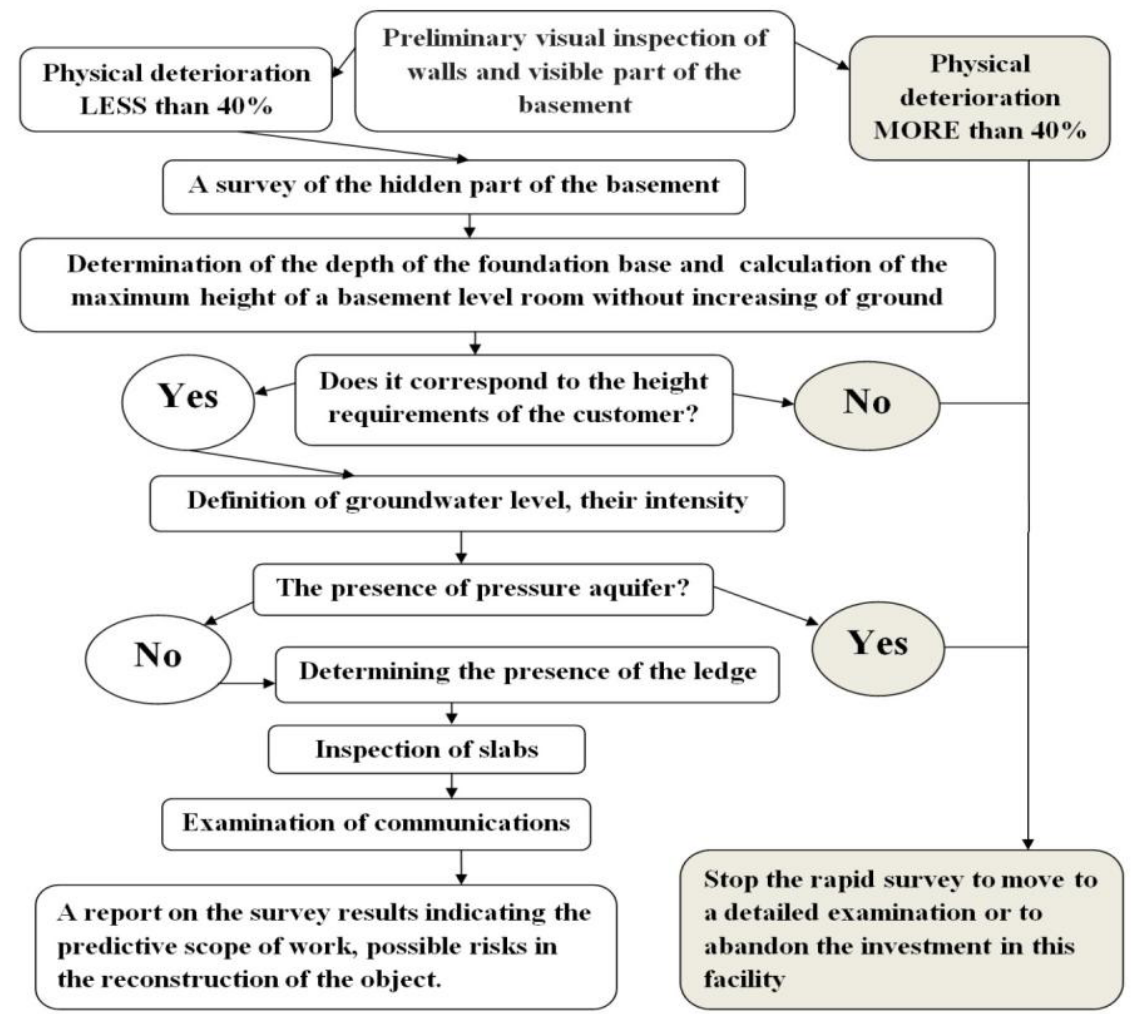

Fig. 1. The algorithm of carrying out a rapid survey of the basement in investment activity.

This algorithm was applied in the examination of a basement on Kazanskaya street in St. Petersburg. The article summarizes the results of this survey. After the initial visual inspection of the walls of the building from the facade and courtyard, walls of a basement are signs of uneven precipitation of the building is not detected. The decision was made to survey the hidden part of the basement. Given the size of the basement (120 square meters), as well as flooring material (clay), the digging pit method of survey was selected. Figure 2 shows a sketch of one of the pits. 


\section{Pit 1(of 6)}

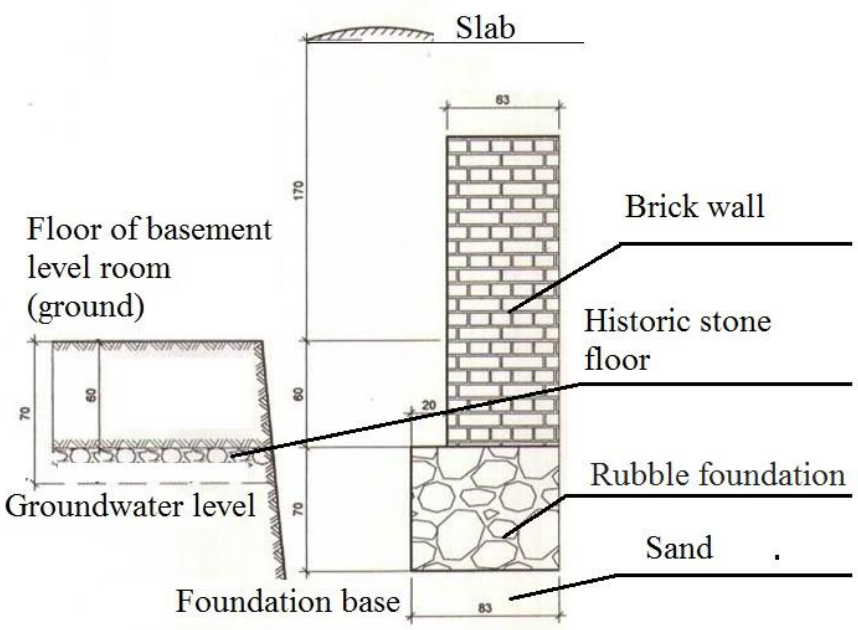

Fig.2. Sketch of test pit

According to the measurement made after excavation the pit, the distance between bottom of Foundation and bottom of the arch is about 300 centimeters. The planned thickness of the floor of the basement is 30 centimeters. Thus, the minimum ceiling height of the room without amplification of the grounds of the building is 220 centimeters to the bottom of the arch ceiling. Groundwater is at 10 centimeters below the planned floor level of the basement. Standard waterproofing with Bentonit plates is recommended. Overlap between the first and basement floors are made as the brick arch. The condition of the arches is satisfactory, significant deformation was not detected.

The results of the survey were established on the materials used in the construction of the Foundation, as well as the material of the base soil of the building. The lower part of the Foundation is made of rubble stone. Masonry made with lime mortar. The upper part of the Foundation is made of brick of high density. On the basis of samples taken from the base of the Foundation established under the Foundation are silty Sands.

\section{Conclusion}

The findings of the rapid survey of the basement level room are:

1. the Existing base of the building is in satisfactory condition, deepening of a basement to the recommended height possible without strengthening the foundations of the building

2. the groundwater level is small, the waters are unconfined in nature

3. ceiling are in satisfactory condition

4. basement is recommended for purchase and renovation.

As mentioned earlier, this rapid survey is used only for decision making about the purchase and reconstruction of a basement level rooms. For the initial design and main works detailed examination are required. However, the method gives to the investor opportunity to determine the volume of upcoming work, to assess the degree of risk in the reconstruction space. Given the inappropriateness of conducting a detailed survey of each room in the presence of a certain number of alternatives, this method can be used by the investor at the stage of decision making about reconstruction. 


\section{References}

1. G. Concu, B., De Nicolo, 11th International Conference on Structural Repairs and Maintainance of Heritage Architecture - Tallinn, 349-358 (2009)

2. G. Leucci, 14th International Conference on Ground Penetrating Radar, 607-609 (2012)

3. S.V. Semencov, M.M. Orehov, V. I. Volkov, Metodika provedeniya obsledovaniy $i$ monitoringa tehnicheskogo sostoyaniya zdaniy s ispolzovaniem peredovih tehnologiy (St-Petersburg, 2013)

4. V.I. Rimshin, V.G. Kazachek, N.V. Nechaev, S.N. Notenko, A.G. Roiman, Obsledovanie $i$ ispitanie zdaniy $i$ sooryjeniy (Stroyizdat, Moskow, 2006)

5. V.G. Kazachek, Obsledovanie zdaniy i sooryjeniy, (Stroyizdat, Moskow, 2006)

6. A.A. Varlamov, V.B. Gavrilov, U.M. Kruciliak, Tehnicheskoe obsledovanie konstrykciy zdaniy i sooryjeniy (RGN, Mignitigorsk, 2007)

7. R.Sh. Adigamov, Opit stroitelstva, eksplyatacii i obsledovaniya fyndamentov zdaniy (Inginerno-Economicheskiy Instityt, Cherepovec, 2007)

8. V.S.Abrashitov, Tehnicheskaya eksplyatacia $i$ obsledovanie stroitelnih konstrykciy (Stroyizdat, Moskow, 2005)

9. A.I. Bedov, Obsledovanie i reconstrukcia jelesobetonnih i kamennih konstrukciy ekspluatiruemih zdaniy i sooryjeniy (Moskow, 1995)

10. A.G. Gindoyan, Posobie po obsledovaniu stroitelnih konstrukciy zdaniy (Informreklamizdat, Moskow, 1997)

11. V.T. Grozdov, Tehnicheskoe obsledovanie stroitelnih konstrukciy zdaniy i soorujeniy (Stroyizdat, St-Peterburg, 2001)

12. A.N. Dobromislov, Ocenka nadejnosti zdaniy i soorujeniy po vneshnim priznakam (Stroyizdat, Moskow, 2004)

13. O.V. Lygin, Obsledovanie i ispitanie sooryjeniy (Stroyizdat, Moskow, 1987)

14. V.V. Meshechek, Posobie po ocenke fizicheskogo iznosa jilih i obshestvennih zdaniy (Stroyizdat, Moskow, 1999)

15. L. Svatovskaya, A. Sychova, M. Sychov, V. Okrepilov, MATEC Web of Conferences, 53, Article Number 01023 (2016)

16. A.V. Ulybin, S.V. Zubkov, Magazine of civil ingineering, (17), 53-56 (2010)

17. Information on http: \www.property-fund.ru

18. A.V. Ulybin, N.I. Vatin, Construction of Unique Buildings and Structures, 10(25), 134-146 (2014)

19. VSN 53-86(p) Pravila ocenki fizicheskogo iznosa jilih zdaniy (Stroyizdat, StPeterdburg, 1986)

20. GOST 31937-2011 Zdaniya i sooryjenia. Pravila obsledovaniya i monitoringa tehnicheskogo sostoyaniya (2012)

21. V.K. Fedulov, L.U. Artemova, Proektirovanie osnovaniy $i$ fundamentov zdani $i$ soorujeniy (MADI, Moskow, 2015)

22. A.M. Kornilov, L.I. Cherkasova, Proektirovanie osnovaniy i fundamentov melkogo zalojenia grajdanskih zdaniy (MGSY, Moskow, 2005)

23. TSN 50-302-2004 SP 50-101-2004

24. A.S. Nikolaev, G.B. Savenkova, Problemi podtopleniya terrioriy Sankt-Peterberga gruntovimi vodami, information on http://www.infoeco.ru/

25. Environmental portal of St. Petersburg, information on http://www.infoeco.ru/

26. S.S. Kolmogorova, Ocenka tehnicheskogo sostoyania bytovih fundamentov pri reconstrukcii zdaniy (Stroyizdat, St-Petersburg, 2007)

27. S.I. Alekseev, Osadki fundamentov pri reconstrukcii zdaniy (Stroyizdat, St-Peterdburg, 2009) 